\title{
A new tuning fork with different vibration frequencies as an aid to bronchopulmonary hygiene physiotherapy
}

José Roberto de Alcântara ${ }^{1}$, Roberta Munhoz Manzano ${ }^{2}$, Maicon Gabriel Gonçalves ${ }^{1}$, Rodrigo Leonel dos Santos ${ }^{1}$, Daniel Donaire Albino ${ }^{3}$, Nadua Apostólico ${ }^{4}$, Nina Teixeira Fonseca ${ }^{4}$, Jéssica Julioti Urbano ${ }^{4}$, Célio Guilherme Lombardi Daibem², Claudio F Donner ${ }^{5}$, Camila Gimenes ${ }^{2}$, Alexandre Ricardo Pepe Ambrozin ${ }^{6}$ and Luis Vicente Franco de Oliveira ${ }^{4 *}$

\begin{abstract}
Background: The main function of the mucociliary system is the removal of particles or substances that are potentially harmful to the respiratory tract. The tuning fork therapeutic for the purpose of bronchial hygiene has still not been described in the literature. The optimal vibration frequency to mobilize secretions is widely debated and varies between 3 and $25 \mathrm{~Hz}$. It is expected that a tuning fork is able to generate vibrations in the thorax, facilitating bronchial hygiene. The aim of the present study is to develop tuning forks with different frequencies, for use in bronchopulmonary hygiene therapy.

Methods: The first tuning fork was made with a fixed frequency of $25 \mathrm{~Hz}$ and it was recorded in the Brazilian institution of patent registration. This device generated a frequency of $25 \mathrm{~Hz}$ and had a weight of $521 \mathrm{~g}$, with dimensions of $600 \mathrm{~mm}$ in total length. The device is characterized by a bottom end containing a transducer with a diameter of $62 \mathrm{~mm}$ and a thickness of 5/16 mm (8"), a rod removable $148 \mathrm{~mm}$, fork length of $362 \mathrm{~mm}$ and an extension at the upper end of sinuous shape bilaterally.The tuning forks must be applied at an angle of $90^{\circ}$ directly on the chest wall of the patient after pulmonary auscultation for location of secretions. The tuning fork is activated by squeezing the tips of the extensions together and releasing them in a sudden movement.

Results: This study shows the result of the development of others three tuning forks of different dimensions to generate different frequencies. Each equipment reaches a fixed frequency preset of 12, 15 and $20 \mathrm{~Hz}$ measured by digital oscilloscope.
\end{abstract}

Conclusions: The tuning fork models developed in this study generated different frequencies proposed by the scientific literature as effective in the mobilization of pulmonary secretions.

Keywords: Airway clearance, Chest wall oscillation, Respiratory therapy, Vibration

\section{Findings}

Mucous membranes in the upper airways, nasal cavity and bronchioles are formed by pseudo-stratified, cylindrical, ciliate epithelium intercalated with submucosal glands and goblet cells, which produce mucus. The upper airways are the first interface among the internal

\footnotetext{
* Correspondence: oliveira.lvf@uninove.br

${ }^{4}$ Master's and PhD Degree Rehabilitation Sciences Program, Universidade Nove de Julho (UNINOVE), Rualtapicuru n 380 apto 111.Perdizes, CEP 05006-000 São Paulo, SP, Brazil

Full list of author information is available at the end of the article
}

environment and microorganisms, allergens and inhaled particles, which are deposited in the respiratory apparatus during breathing [1]. The main function of the mucociliary system is the removal of particles or substances that are potentially harmful to the respiratory tract through transport by the cilia or the action of coughing or sneezing in situations involving the overproduction of mucus, such as allergic rhinitis, sinusitis, chronic bronchitis, cystic fibrosis and asthma $[1,2]$.

The cilia are responsible for mucociliary clearance. The number of cilia per cell ranges from 50 and 100 and 
is influenced by age and position in the respiratory tract [3]. Under normal conditions, the cilia of the septal mucosa and inferior turbinates beat at a frequency of 12 to $15 \mathrm{~Hz}$ (beat/second). This rhythm follows a coordinated sequence, producing a metachronal wave, the control mechanism of which remains unknown. The metachronal wave directs the flow of mucus in the nasal cavities toward the nasopharynx, oropharnyx and hypopharynx, where the secretion is swallowed [3].

Ultra-structural alterations of the cilia, such as the absence of inner or outerdyne in arms and the deletion or transposition of pairs of central or peripheral microtubules, lead to significant changes in the ciliary rhythm frequency and pattern, thereby causing the stasis of secretion and repeated respiratory infection, as occurs in primary ciliary dyskinesia $[4,5]$. Ciliary rhythm is dependent on the viscoelastic properties and clearance of the respiratory mucus. The lining of the ciliate epithelium is composed of respiratory mucus and periciliary fluid. In disease conditions, there is an intense change in the composition of the mucus, with direct and indirect effects on mucociliary function, mainly due to changes in the viscoelastic properties of the respiratory mucus [3]. Considering the importance of changes in mucociliary clearance to the physiology of the airways, it is fundamental to develop methods that allow an analysis of mucociliary clearance in both the experimental setting and clinical practice [3].

Respiratory physical therapy is an effective resource in the prevention and treatment of different respiratory diseases and consists of maneuvers designed to increase lung expansion and eliminate secretions [6]. Bronchopulmonary hygiene maneuvers are a form of respiratory physical therapy involving thoracic percussion and postural drainage for the removal of pulmonary secretions. These procedures are commonly performed in patients with acute or chronic airway disease conditions. The literature shows divergent results regarding the efficacy of these maneuvers. Nonetheless, such procedures continue to be widely used in clinical practice [7]. The most often employed respiratory physical therapeutic maneuvers are pulmonary percussion, assisted cough, cough stimulation, forced expiratory maneuvers, diaphragm and costal stimulation, postural drainage, and vibrocompression (combination of vibration and compression) [6]. A literature review on percussion, vibration, high-frequency oscillation, and mechanical compression of the thoracic wall in the clearance of the airways concluded that mechanical vibration may enhance mucociliary clearance and that high-frequency thoracic compression is more promising than high-frequency oral oscillation [8].

In a study involving physical therapists with experience in intensive care units, three sets of eight vibrations were applied to the thoracic wall of an intubated dummy on mechanical ventilation. The vibrations were applied at the onset of expiration (optimal), from the middle to the end of inspiration (early) and from the onset to the middle of expiration (late). Air flow, peak inspiratory pressure, and volume were measured continuously. The forces applied during the vibrations were recorded by a sensor under the hands of the physical therapist. The authors concluded that that safety and efficacy of respiratory physical therapy are influenced by the rhythm of the vibrations within the respiratory cycle; early vibrations can increase peak inspiratory pressure, whereas late vibrations, while not harmful, are not effective at increasing peak expiratory flow [9].

The indication of respiratory physical therapy in children with bronchiolitis is controversial and there is no evidence of its efficacy in improving the clinical status of patients [10-12]. Moreover, bronchopulmonary hygiene modalities and auxiliary devices are limited in clinical practice by the presence of alterations in the thoracic cage stemming from osteoporosis, which renders percussion unviable, or the level of consciousness required for the use of the Flutter device $[13,14]$. In order to enrich bronchopulmonary hygiene methods and enable the treatment of patients who exhibit these limitations, it is necessary to develop a piece of equipment that is not affected by such limitations.

According to Lyon Consensus Conference (1994), vibrations, by non-instrumental means, in an oscillatory motion should be applied to the chest to obtain a desired optimal frequency, from 3 to $75 \mathrm{~Hz}$, thereby modifying the rheology of the bronchial mucus. When using the manual Technical Production, if induces a frequency of 1-8 Hz, unable to perform bronchial assistance for the transport of mucus [15].

Due to the discrepancies in the literature on the ideal frequency for an effective vibration, the design of a tuning fork is suggested for therapeutic purposes based on the fact that such an instrument produces mechanical vibrations that can trigger the thixotropic property of mucus and can be implemented in situations in which manual therapy is contraindicated, such as in cases of ribs fractures or osteoporosis.

\section{Objective}

The aim of the present study is to develop tuning forks with different frequencies, for use in bronchopulmonary hygiene therapy.

\section{Availability and requirements}

This study was carried out at the Faculdades Integradas de Bauru (SP), Brazil and received approval from the Ethics committee of the same institution under process number 022/11 OSH. 
The tuning forks must be applied at an angle of $90^{\circ}$ directly on the chest wall of the patient after pulmonary auscultation for location secretion. The operation of the device occurs when there is an approximation of the winding extensions by means of a tweezers movement and subsequent abrupt withdrawal of the fingers generating mechanical vibration (Figure 1 ).

The first tuning fork was made with a fixed frequency of $25 \mathrm{~Hz}$ and it was recorded in the Brazilian institution of patent registration: InstitutoNacional de Propriedade Industrial (INPI) with the title: Device Oscillator Thoracic Hardeners (DIOTTIX). The patent was called Utility Model (UM), under the process number: 9101697-5. This device generate a frequency of $25 \mathrm{~Hz}$ has a weight of $521 \mathrm{~g}$, with dimensions of $600 \mathrm{~mm}$ in total length. The bottom end containing a transducer with a diameter of $62 \mathrm{~mm}$ and a thickness of 5/16 $\mathrm{mm}\left(8^{\prime \prime}\right)$, has a rod removable $148 \mathrm{~mm}$, fork length of $362 \mathrm{~mm}$ and an extension at the upper end of sinuous shape bilaterally.

\section{Results}

This study shows the result of the development of other three tuning forks of different dimensions to generate different frequencies. The device with a frequency of $12 \mathrm{~Hz}$ has a weight of $1,199 \mathrm{~g}$, and dimensions of $638 \mathrm{~mm}$ in total length, the bottom end containing a transducer with a diameter of $62 \mathrm{~mm}$ and a thickness of 5/16 mm $(8 ")$, a removable rod of $148 \mathrm{~mm}$, a fork of $362 \mathrm{~mm}$ length and an extension at the upper end of sinuous shape bilaterally.

The tuning fork with the frequency of $15 \mathrm{~Hz}$ has a weight of $842 \mathrm{~g}$ and dimensions of $626 \mathrm{~mm}$ in total length, the bottom end containing a transducer with a diameter of $62 \mathrm{~mm}$ and a thickness of 5/16 $\mathrm{mm}\left(8^{\prime \prime}\right)$, a removable rod $148 \mathrm{~mm}$, fork length of $362 \mathrm{~mm}$ and an extension at the upper end of sinuous shape bilaterally. The device with the frequency of $20 \mathrm{~Hz}$ has a weight of $608 \mathrm{~g}$, its dimensions were $630 \mathrm{~mm}$ in total length, the bottom end containing a transducer with a diameter of $62 \mathrm{~mm}$ and a thickness of 5/16 mm (8"), a rod removable

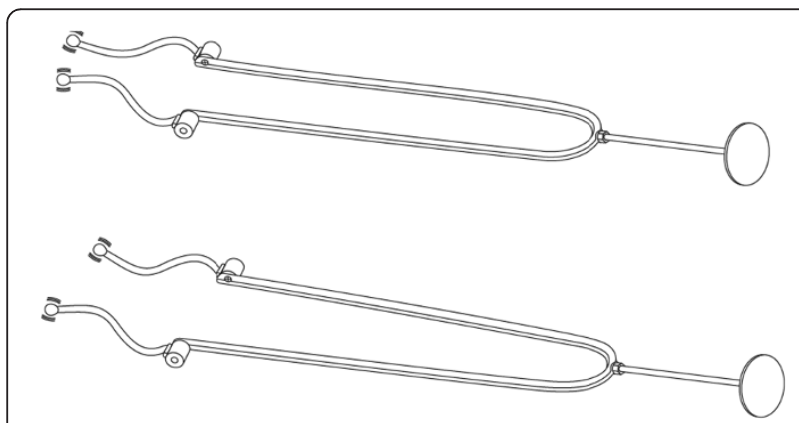

Figure 1 Tuning fork device. (Above) approximation of the extensions; (below) complete squeezing movement.
$148 \mathrm{~mm}, 362 \mathrm{~mm}$ of a fork length and an extension at the upper end of sinuous shape bilaterally.

The operation of the tuning forks occurs when there is an approximation of the extensions of the sinuous shape by means of a pincer movement and subsequent abrupt withdrawal of the fingers generating mechanical vibration (Figure 2). With certain devices achieving the desired frequencies, using different weights and fine tuning fork end was required.

The tuning forks is a generator of mechanical waves. To measure the frequency generated by the device was necessary to transform the energy generated by the equipment, from mechanical nature to electrical oscillation. In this procedure a piezoelectric crystal transducer was used, because this component has the ability to generate electric current in response to a mechanical pressure. Applying the piezoelectric crystal on the basis of the transducer, the energy from the mechanical oscillation into electrical current was obtained, thus making possible the visualization of the signal generated by the oscilloscope through. To measure the frequency generated by the tuning forks they were coupled to a piezoelectric crystal and the oscilloscope displays the amplitude and frequency of the waves. Each tuning fork was verified individually. The frequency of mechanical vibration hit by developed pitch (12, 15 and $20 \mathrm{~Hz}$ ) was measured by a digital oscilloscope (Tektronix, Model: TDS 220, 100 MHz, Sao Paulo - SP, 1995).

\section{Discussion}

The tuning fork was created by John Shore in 1711 for musical purposes. This device is a steel fork that produces a sound vibration at a particular frequency when struck [16]. Ernest Heinrich Weber, German physician, professor of anatomy and physiology at the University of Leipzig, was the first to describe the use of the tuning fork in medicine in 1825 . Weber believed that his experiences with the tuning fork in medicine would be used one day for the diagnosis of hearing problems, so he created the Weber test, with the aim to differentiate

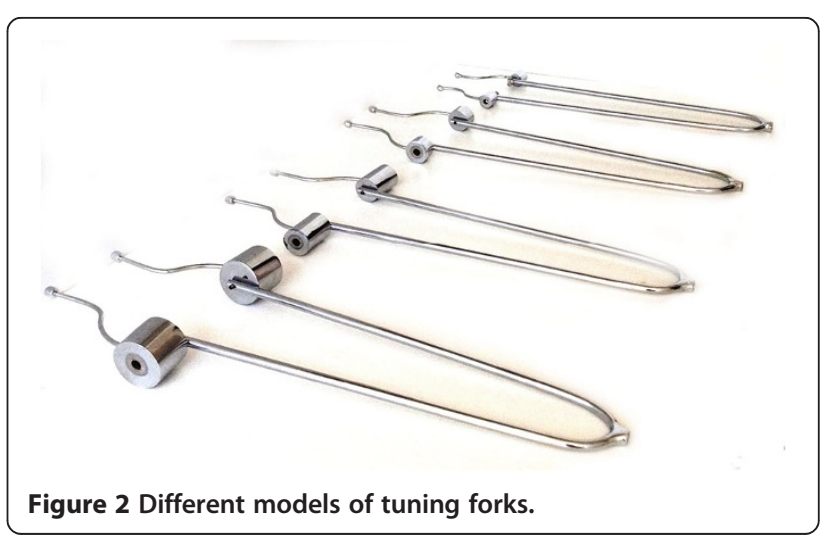


conductive and sensory hearing loss. In 1855, Heinrich Adolf Rinne used a tuning fork to differentiate bone conduction from air conduction on the same side of the head in hearing loss (Rinne test). Both the Weber and Rinne test continue to be employed in clinical practice and are widely cited in the scientific literature [17].

The tuning fork with $128 \mathrm{~Hz}$ is routinely used in neurologic medicine for diagnostic purposes. Vibratory sensitivity (paresthesia) is determined through contact between the tuning fork and bone prominences. A reduction or absence of vibratory sensitivity may indicate injury or disease of the peripheral nerves or dorsal columns of the spinal cord [18]. The use of a tuning fork in the detection of fractures is infrequent in literature. The first study about this topic was carried out by Bache and Cross (1984), who studied the use of a tuning fork and stethoscope on femur fractures [16]. The $128 \mathrm{~Hz}$ tuning fork and stethoscope have also been used to differentiate sound conduction between injured and healthy limbs [19]. In 1997, Moore used a tuning fork and stethoscope to assess possible long bone fractures [20].

Vibration is a rhythmic or random movement of a structural element or machine part - a repetitive movement from a position of rest. In nature, numerous systems oscillate around a position of rest. In real-world systems, such oscillations are normally dampened, diminishing gradually with time without the application of any external stimulus. This effect stems from the dissipation of energy that occurs during the oscillations (Moore MB: The use of a tunning fork and stethoscope in evaluating possible fractures. Unpublished master's thesis. 1997). To propagate the oscillations is necessary to have elastic properties. The movement of a vibrating body is transmitted to the adjacent molecules, which transmit this movement to surrounding molecules before returning to a state of equilibrium [16].

The oscilloscope is a device that allows the graphic visualization of electrical signals, demonstrating how a signal varies over time on the vertical axis (Y), representing the amplitude of the signal (tension), horizontal axis $(\mathrm{X})$, representing time, and $\mathrm{Z}$ axis, representing intensity (brightness). This device allows to determine the continual and alternating components of a signal, detecting (and sometimes eliminating) noise interference and comparing two signals (digital or analog) in a given circuit in both the input and output of the components. This equipment is used in numerous applications, such as the analysis of the functioning of the electronic control units of an automobile, vibration analysis of a motor and the analysis of signal conditioning circuits for instrumentation systems and biomedical systems [21].

Respiratory mucus is a non-Newtonian fluid, whose mechanical properties are altered in accordance with the intensity and frequency of the force applied to it. Thus, studies addressing the action of this frequency on mucus are of considerable importance, as low-frequency stimuli (1 to 10 radians/second) reflects the transport by mucus and high-frequency stimuli (100 radians/second) simulates coughing or sneezing [3]. The ideal vibration frequency capable of mobilizing the largest amount of secretions is a subject of debate. For greater efficiency, vibrations should meet the following criteria: application on region to be treated in perpendicular direction during expiration, with a frequency ranging from 3 to $25 \mathrm{~Hz}$ [22]. Another study reports that the best frequency for secretions clearance is between 12 and $17 \mathrm{~Hz}$. However, clinical trials have not demonstrated greater efficacy in high-frequency oral oscillation $(9.2$ to $25 \mathrm{~Hz})$ in comparison to conventional physical therapy in patients with chronic bronchitis or cystic fibrosis [23,24]. The intratracheal oscillation generated by the Flutter ${ }^{\circ}$ VRP1 device ranges from 6 to $20 \mathrm{~Hz}$ in the expiratory phase [25].

Jones and Rowe (2011) carried out a systematic review of randomized studies involving forced expiration, coughing, thoracic percussion, vibration and postural drainage in individuals with chronic obstructive pulmonary disease (COPD) and bronchiectasis. Only seven studies fulfilled the inclusion criteria, totaling 126 patients. In the majority of comparisons, bronchopulmonary hygiene procedures did not produce significant effects regarding improvements in secretion clearance or lung function. The authors concluded that these data do not support the indication or contraindication of bronchopulmonary hygiene by means of physical therapy in patients with COPD or bronchiectasis [7]. Another study reports that an increase in support pressure in intubated patients increases mucociliary clearance, whereas the addition of manual vibration with thoracic compression in combination with this increase in support pressure does not offer benefits regarding bronchopulmonary hygiene [26].

A systematic review was carried out in 2011 on randomized studies including forced expiratory maneuvers, cough, thoracic percussion, vibration and postural drainage in patients with COPD and bronchiectasis. In the majority of the studies the techniques of bronchial hygiene produced significant improvements related to a better removal of secretions and to a better lung function, but the authors concluded that there is not enough evidence to suggest or not suggest the bronchial hygiene maneuvers in patients with COPD or bronchiectasis [9].

In some respiratory diseases like COPD, asthma, bronchiectasis and cystic fibrosis, characterized by a large production of mucus, there could be a reduction ofmucociliary clearance and an increase in mucus production, which consequently affects the flow and the permeability of the airways, and causes inflammation. In this context it is fundamental to develop methods that improve 
mucociliary transport [27]. Inside the respiratory therapy there are multiple techniques that improve and optimize the bronchial hygiene contributing to a better ventilation, oxygenation and pulmonary function. The manual respiratory techniques and the auxiliary devices to bronchial hygiene present some clinical limitations, like broken ribs and hemodynamic instability that limited chest wall percussion. On the other hand, the decrease in conscious level and endotracheal tube limited the use of Oscillating Positive Expiratory Pressure Devices [7,14,28].

The DIOTTIX (Dispositivo Oscilador Torácico Tixotrópico, patente para aprovação, Vilage Marcas e Patentes S/S Ltda., as. 84172) device has never been used in the clinical practice with the bronchial hygiene purpose. This device has a promising future in respiratory therapy, but we need to understand all effects before propose it as a technique. It is very important to carry out abasic research with DIOTTIX, however the purpose of this study is only the development and laboratory testing of three different models of tuning forks with different vibration frequencies. The next step will be represented by the performance evaluation of DIOTTIX in healthy subjects and in COPD patients to determine whether the frequency of $12,15,20$ e $25 \mathrm{~Hz}$ respectively, when applied to thorax, effectively reach the calibrated frequencies. Finally, it will be needed to evaluate the efficacy in mobilizing lung secretions. We are going to carry out this assessments in the next future.

\section{Conclusions}

The tuning fork models developed in this study generated different frequencies proposed by the scientific literature as effective in the mobilization of pulmonary secretions. Therefore, it can be used as a technique of bronchopulmonary hygiene in respiratory therapy. However, the paucity of studies in this area emphasizes the need for more research on the frequency of vibration and wave propagation in the thorax.

\section{Competing interests}

The authors declare that they have no competing interests.

\section{Authors' contributions}

All the authors contributed to the conception and design the study. LVFO, JRA and RMM provided the idea for the study, established the hypothesis and wrote the original proposal. JRA, RMM, MGG, RLS, DDA, NA, NTF, JU, CGLD, CFD, CG, ARPA and LVFO will participate in the conduct with clinical screening tests, application of psychological instruments, and data analysis. JRA, RMM, MGG, RLS, DDA, NA, NTF, JJU, CGLD, CFD, CG, ARPA and LVFO significantly contributed to writing this paper, while JRA, RMM, MGG, NA, NTF, JJU, ARPA and LVFO were involved in critically revising the manuscript. This protocol paper was written by LVFO, JRA and RMM with input from all co-authors. All authors read and approved the final manuscript.

\section{Acknowledgements}

Acknowledgments are for "Faculdades Integradas de Bauru".

\section{Author details}

${ }^{1}$ Graduated in Faculdades Integradas de Bauru, Bauru, SP, Brazil. ${ }^{2}$ Physical Therapy Course in FaculdadesIntegradas de Bauru, Bauru, SP, Brazil. ${ }^{3}$ Universidade Paulista (UNIP), Bauru, SP, Brazil. ${ }^{4}$ Master's and PhD Degree Rehabilitation Sciences Program, Universidade Nove de Julho (UNINOVE), Rualtapicuru n 380 apto 111.Perdizes, CEP 05006-000 São Paulo, SP, Brazil. ${ }^{5}$ Mondo Medico, Multidisciplinary and Rehabilitation Outpatient Clinic, Borgomanero, NO, Italy. ${ }^{6}$ Physical Therapy Course in Universidade Estadual Paulista "Julio de Mesquita Filho" (UNESP), Marília, SP, Brazil.

Received: 30 May 2014 Accepted: 7 July 2014

Published: 1 August 2014

\section{References}

1. Blanco EEA, Pinge MCM, Neto OAA, Pessoa NG: Effects of nitric oxide in mucociliary transport. Braz J Otorhinolaryngol 2009, 75(6):866-871.

2. Macchione M, Guimaraes ET, Saldiva PH, Filho LG: Methods for studying respiratory mucus and mucus clearance. Braz J Med Biol Res 1995, 28(12):1347-1355

3. Trindade SH, de Mello JF Jr, Mion Ode G, Lorenzi-Filho G, Macchione M, Guimarães ET, Saldiva PH: Methods for studying mucociliary transport. Braz J Otorhinolaryngol 2007, 73(5):704-712.

4. Bush A, Cole P, Hariri M, Mackay I, Phillips G, O'Callaghan C, Wilson R, Warner JO: Primary ciliary dyskinesia: diagnosis and standards of care. Eur Respir J 1998, 12:982-988.

5. Olm MAK, Adde FV, Silva Filho LV, Rodrigues JC: Discinesia ciliar primária: quando o pediatra deve suspeitar e como diagnosticar? Rev Paul Pediatr 2007, 25(4):371-376.

6. Haddad ER, Costa LCD, Negrini F, Sampaio LMM: A borda gens fisioterapêuticas para remoção de secreções das vias aéreas em recém-nascidos: relato de casos. Pediatr (São Paulo) 2006, 2(28):135-140.

7. Jones AP, Rowe BH: Withdrawn: Bronchopulmonary hygiene physical therapy for chronic obstructive pulmonary disease and bronchiectasis. Cochrane Database Syst Rev 2011, 7:CD000045.

8. Goodwin JM: Mechanical chest stimulation as a physiotherapy aid. Med EngPhys 1994, 16:267-272.

9. Shannon H, Stiger R, Gregson RK, Stocks J, Main E: Effect of chest wall vibration timing on peak expiratory flow and inspiratory pressure in a mechanically ventilated lung model. Physiotherapy 2010, 96(4):344-349.

10. American Academy of Pediatrics Subcommittee on Diagnosis and Management of Bronchiolitis: Diagnosis and management of bronchiolitis. Pediatrics 2006, 118(4):1774-1793.

11. Perrotta C, Ortiz Z, Roque M: Chest physiotherapy for acute bronchiolitis in paediatric patients between 0 and 24 months old. Cochrane Database Syst Rev 2005, 2:CD004873.

12. Pupin MK, Riccetto AGL, Ribeiro JD, Baracat ECE: Comparison of the effects that two different respiratory physical therapy techniques have on cardiorespiratory parameters in infants with acute viral bronchiolitis. J Bras Pneumol 2009, 35(9):860-867.

13. Faling JL: Pulmonary rehabilitation: physical modalities. Clin Chest Med 1986, 4(7):599-617

14. Silveira ACT: Uso da oscilaçãooral de alta frequência em paziente ventilados mecanicamente, um estudo prospectivo e revisão de literatura. Cadernos Uni FOA - Ano II 2007, 4:104-110.

15. Lyon, FR: Conferénce de Consensussur la Kinésithérapie Respiratoire, 1994 Déc. 2-3. KinesitherScientif 1995, 344(4):45-54.

16. Alcantara JR, Santos RL, Albino DD, Manzano RM: Desenvolvimento de aparelho de diapasão como uma ferramenta auxiliarnas manobras de higiene brônquica para fisioterapeutas. Conscientiae Saúde 2012, 11(4):529-534.

17. Meirelles FO, Duarte MS: Resposta ao teste do diapasão em indivíduos com fraturas diagnosticadas; 2010. Disponívelem: [https://www.yumpu.com/pt/ document/view/15350310/resposta-ao-teste-do-diapasao-emindividuosfrasce]. Acesso em: 28 out.

18. Bickerton RC, Barr GS: The origin of tuning fork. J R Soc Med 1987, 80:771-773

19. Butlher DS: Mobilização do Sistema Nervoso. 1st edition. Barueri: Manole; 2003.

20. Misurya RK: Use of tuning fork in diagnostic auscultation of fractures. Br J Accid Surg 1987, 18:63-64.

21. Paker SP: Study on the influence of vibration on task execution aircraft pilots. [Masterdegreethesis]. São Paulo: EscolaPolitécnica da Universidade de São Paulo; 2008 
22. Alves MF, ABC do osciloscópio: Instituto Politécnicodo Porto Departamento de Engenharia Electrotécnica. 2nd edition. ; 1998.

23. Gomide LB, Silva CS, Matheus JPC, Torres LAGMM: Atuação da fisioterapia respiratória em paziente com fibrosecística: um arevisão da literatura. Arq Ciênc Saúde 2007, 14(4):227-233.

24. Liebano RE, Hassen MAS, Mazzi HH, Racy J, Correa JB: Principais manobras cinesioterapêuticas manuais utilizadas na fisioterapia respiratória: descrição das técnicas. Rev Ciênc Méd 2009, 18(1):35-45.

25. Van Hengstum M, Festen J, Beurskens C, Hankel M, van den Broek W, Corstens F: No effect of oral high frequency oscillation combined with forced expiration manoeuvres on tracheobronchial clearance in chronic bronchitis. Eur Respir J 1990, 3(1):14-18.

26. NaueWda S, da Silva AC, Güntzel AM, Condessa RL, de Oliveira RP, Rios Vieira SR: Increasing pressure support does not enhance secretion clearance if applied during manual chest wall vibration in intubated patients: a randomised trial. J Physiother 2011, 57(1):21-26.

27. Van Der Schans CP: Bronquial mucus transport. Respir Care 2007, 52(9):1150-1158

28. Bott J, Blumenthal S, Buxton M, Ellum S, Falconer C, Garrod R, Harvey A, Hughes T, Lincoln M, Mikelsons C, Potter C, Pryor J, Rimington L, Sinfield F, Thompson C, Vaughn P, White J, British Thoracic Society Physiotherapy Guideline Development Group: Guidelines for the physiotherapy management of the adult, medical, spontaneously breathing patient. Thorax 2009, 64(Suppl.1):i1-i51.

doi:10.1186/2049-6958-9-41

Cite this article as: de Alcântara et al:: A new tuning fork with different vibration frequencies as an aid to bronchopulmonary hygiene physiotherapy. Multidisciplinary Respiratory Medicine 2014 9:41.

\section{Submit your next manuscript to BioMed Central and take full advantage of:}

- Convenient online submission

- Thorough peer review

- No space constraints or color figure charges

- Immediate publication on acceptance

- Inclusion in PubMed, CAS, Scopus and Google Scholar

- Research which is freely available for redistribution 